(C) Shkodina A.D., Hrinko R.M., Starchenko I.I.

UDC 611.813.3+612.825.56]:614.7

DOI https://doi.org/10.31718/mep.2019.23.3-4.09

\title{
MODERN CONCEPTION AS TO THE FUNCTIONAL MORPHOLOGY OF THE OLFACTORY SYSTEM AND ITS CHANGES UNDER THE INFLUENCE OF SOME EXOGENOUS POLLUTANTS
}

\author{
Shkodina A.D., Hrinko R.M., Starchenko I.I. \\ Ukrainian Medical Stomatological Academy, Poltava, Ukraine
}

\begin{abstract}
Взаємодія людини з навколишнім середовищем забезпечує основні аспекти ії життєдіяльності. Вирішальну роль при цьому відіграють дистантні аналізатори. Дослідження функціональної будови нюхового аналізатора посідає важливе місце як в клінічних, так і в експериментальних дослідженнях, однак питання його особливостей саме в людини потребує детальних досліджень. У роботі наведені сучасні дані вітчизняних і зарубіжних дослідників, що стосуються структурно-функціональної організації нюхового аналізатора. Особливу увагу приділено структурній організації нюхових цибулин, як найбільш складно влаштованого і найменш вивченого компонента нюхового аналізатора. Описано морфологічні та функціональні зміни нюхового аналізатора, що розвиваються при деяких захворюваннях і дії несприятливих чинників навколишнього середовища, при цьому акцентується увага на відмінності механізму патогенезу ушкоджень нюхового аналізатора в залежності від характеру впливу патогенних чинників. Так, в результаті нетривалого інтенсивного впливу полютанту незворотніх атрофічних змін в першу чергу зазнає нюховий епітелій, тим самим, в де який мірі, запобігаючи поширенню токсину на інші структури аналізатору. I навпаки, тривалий вплив низьких доз зазвичай зберігає функціональну активність нюхового епітелію, натомість шкідливі речовини проникають до центрального відділу нюхового аналізатора. В таких випадках нюхова дисфункція може діагностуватися через тривалий час після початку контакту з певними полютантами. На сьогодні досить активно проводяться дослідження впливу екзогенних токсинів на різні ланки нюхового аналізатора на тваринних експериментальних моделях. В той же час питання функціонально - морфологічних змін в різних структурних компонентах нюхового аналізатора людини під впливом негативних факторів довкілля залишається недостатньо вивченим і потребує подальших морфологічних та біохімічних досліджень, з метою можливості в подальшому розробки дієвих лікувальних та профілактичних засобів.
\end{abstract}

Ключові слова: нюховий аналізатор, нюхові цибулини, мітральні клітини, нюхова дисфункція.

The interaction between a body and an environment provides the main aspects of human life. The study of the functional structure of the olfactory analyzer plays an important role both in clinical and in experimental studies, but the question of its features in humans needs detailed research. The paper presents the modern data of the structural and functional organization of the olfactory analyzer. Particular attention is paid to the structural organization of olfactory bulbs as most complicated and least studied component of the olfactory analyzer. The morphological and functional changes of the olfactory analyzer are developing in some diseases and in action of adverse environmental factors are described while the accentuation is placed on the differences of the mechanism in the pathogenesis of damage to the olfactory analyzer, depending on the nature of the influence of pathogenic factors. In this way as the result of shortterm intense effects of the pollutant, irreversible atrophic changes are primarily affected to the olfactory epithelium, thus, to some extent, preventing the spread of the toxin to other analyzer structures. Conversely, a long-term exposure to low doses usually retains the functional activity of the olfactory epithelium, while harmful substances penetrate the central unit of the olfactory analyzer. In such cases, the olfactory dysfunction can be diagnosed after a long time after the start of the cohort with certain pollutants. Currently, studies of the influence of exogenous toxins on various parts of the olfactory analyzer on animal experimental models are quite active. At the same time, the issue of functional and morphological changes in various structural components of the human olfactory analyzer under the influence of negative environmental factors remains poorly understood and requires further morphological and biochemical studies, in order to be able to further develop effective therapeutic and prophylactic means.

Key words: olfactory anylazer, olfactory bulbs, mitral neuron, olfactory dysfunction.

The human interaction with environment underlies the main aspects of our life. A decisive role belongs to distant analyzers - olfactory, visual and auditory. From the evolutionary point of view, the sense of smell is one of the most ancient and most essential sensations through which the process of acknowledgement of the external world takes place. For most mammalian species, the analysis of odorants determines the complex forms of behavior on which their lives depend. Unlike other analyzers, chemosensory systems are dynamic throughout the period of ontogenesis, due to processes of continuous renewal of the olfactory epithelium [32].

The study of functional structure of the olfactory analyzer plays an important role both in clinical and in experimental studies, but the question of its features in humans needs detailed research.

As is known, the peripheral part of the olfactory analyzer is represented by specific receptors, which are located in the mucous membrane of the upper nasal passage and the posterior-upper part of the nasal

To cite this english version: Shkodina A.D., Hrinko R.M., Starchenko I.I. Modern conception as to the functional morphology of the olfactory system and its changes under the influence of some exogenous pollutants. // The Medical and ecological problems. - 2019. Vol 23, № 3-4. - P. 37-40. 
membrane. Even then, the smell area occupies a relatively small area (approximately $2.5 \mathrm{~cm}^{2}$ on each side) and contains about 50 million sensory cells [7].

Olfactory receptors are relict forms that are represented in the vertebrates. During the embryogenesis, they lay and develop in the anterior frontal brain, their bodies migrate to the olfactory plate, and the axons contact with the neurons of the olfactory bulb, which contains olfactory glomeruli, the most ancient of the known synapses. The results of individual studies indicate that the primary olfactory center in the human body begins to function not earlier than at the 30th week after the natal period of development [26].

The zonal organization of the olfactory system is determined not only by the peculiarities of the expression of the genes of the olfactory receptors, but also by the geometry of the nasal passages, where the receptors for more flammable substances are located in the dorsal part, whereas the receptores for the more volatile ones in the ventral part [23]. The structural organization of the olfactory epithelium does not have structural features peculiarities in the elderly. However, in elderly individuals, the ability to recognize odors is reduced, which is probably due to pathological changes in the blood vessels in the cortical sections of the analyzer [4].

It is now known that olfactory sensations arise from the interaction of the odorous substance (odorant) with the chemoreceptors of the neurosensory epithelium of the nasal cavity. This leads to the launch of cascades of biochemical reactions and the emergence of action potential.

The leading way of the olfactory analyzer has a complex structure. The first neuron is formed by bipolar cells, the dendrites of which travel to the free surface of the mucous membrane, where the olfactory bubbles end, and the axons form the olfactory threads, 15-20 on each side. Through the perforated plate of the lattice bone, they penetrate into the cavity of the skull, where they form synapses with the second neuron, which is in the olfactory bulb [28].

Olfactory bulbs are located in the anterior cranial fossa, on the lower surface of the frontal lobes of the cerebral hemispheres, from where it continues into the olfactory pathway, and represent a set of nerve cells, glial cellular elements, blood microvessels, fibrillar structures. Externally, each olfactory bulb is surrounded by a specific capsule, formed by pia mater and arachnoidea. It is believed that an increase of the density of blood capillaries in ontogenesis and the ripening of neurons occurs much faster in the olfactory bulb, ammonium, and olfactory gyrus than in other parts of the brain [20]. In a healthy person, the average volume of the olfactory bulb is $65-70 \mathrm{~mm}^{3}$ and correlates with the functional activity of the olfactory system [13].

The role of human olfactory bulbs remains one of the most interesting questions about the brain, since this organ is one of the few whose interneurons are continuously generated in postnatal and adult life. Their main functions are the threshold of perception, discrimination and identification of odors [31].

In the study of the internal structure of olfactory bulbs, using classical histological techniques, the following five basic cell layers, which differ in morphological and, consequently, functional characteristics, are usually distinguished (Figure 1):

glomerular

external pleximorphic;

a layer of mitral cells;

internal pleximorphic;

a layer of granular cells.

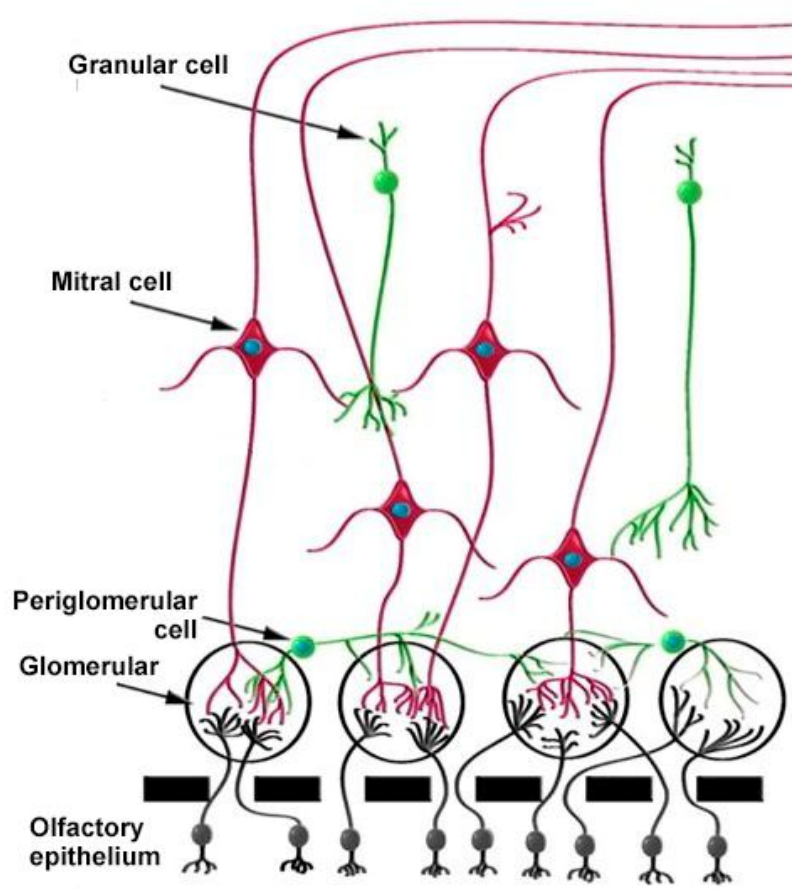

Figure 1. Schematic cell composition of the human olfactory bulb [27].

The most external (subcapsular) position is the glomerular layer, which received this name due to the arrangement of cellular elements located in here and nerve fibers in a peculiar glomerular structure. The glomerular layer thickness index and glomerular volume were well studied in many animals, while in humans, this figure was not determined [27].

The outer plexiform layer is internally located and is characterized by a small number of small-scale neurocytes, which are surrounded by a large number of glial and fibrillar elements.

The granular layer is characterized by the location of cells in the form of relatively even series. The cellular elements of the inner plexiform layer practically do not differ from such external elements [15].

The mitral cell layer is arranged in the form of a concentric series or series filled with cells, the shape of which pericarion passes through the central part, resembling a triangular mitra, and being the reason for its name. Mitral neurocytes are phylogenetically the most ancient and largest cells of the brain; their total number is relatively small and accounts for approximately $1 \%$ of the entire cellular population of olfactory bulbs. Modern researchers distinguish three types of mitral cells according to their form and functional features: triangular, ball-like and funnel-shaped [1]. A characteristic feature of mitral cells is the presence of a dendritic protoplasmic barrel, which goes to the glomerular zone, where it forms a dense branching, and the axons pass along with the axons located near the periglomerular cells to the limbic system.

Central synaptic odor processing begins in the glomerular glomeruli layer of olfactory bulbs, which receive information from thousands of receptor cells. A ball of glomeruli is a kind of "spatial odor map", which is divided into zones and clusters [25].

The mitral cells of the olfactory bulb, being another neurons of the olfactory pathway, recognize the nature of the signals received from the primary sensory cells and exhibit the greatest selectivity to the odorant [14].

It has been proved that mitral cells differ in molecular expression of profiles of potential-dependent potassium 
and channel-dependent cyclic nucleotide. The latter are activated due to hyperpolarization and are closely related to the glomerular modulus, indicating the influence of sensory neuronal activity on the functioning of these structures [22].

Local interneurons (periglomerular and granular) of olfactory bulbs perform lateral inhibition, which provides the contrast between odors. At these neurons, the efferent paths from the opposite olfactory bulb, the limbic system and reticular formation end; in the plexiform layer, the apical dendrites from the brachial cells form a large number of synapses with mitral cells that regulate the proliferation of activity action along cell dendrites. [9]

The braking created by the granular cells, which are the most common type of GABA-ergic cells, occurs due to single dendro-dendritic synapses. In this case, the mitral cells release the excitatory neurotransmitter glutamate. Due to its bi-directionality, it can lead to inhibition of mitral cells (autoinhibition), as well as neighboring mitral cells (lateral inhibition) [11].

The ratio of the activity of the allocation of neurotransmitters by different cellular populations of olfactory bulbs provides differentiation of odorants (Figure 2) [10].

Most of the projection areas of the olfactory tract do not directly participate in the perception of odors, their physiological role is to create associative relationships with other sensory systems. For example, activation of the limbic system causes the appearance of emotional component in the olfactory perception and plays an important role in the memory processes.

Because of the reticular formation, the olfactory system is closely linked to the autonomic nervous system, which explains reflex responses from the digestive and respiratory systems.

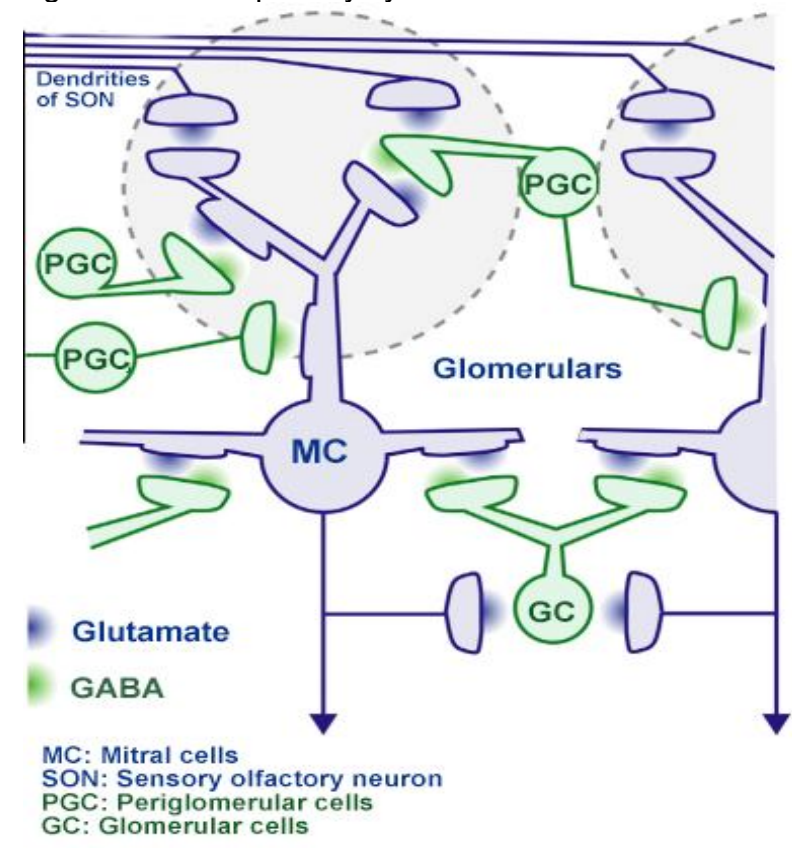

Figure 2. Scheme of the interaction of cell populations of olfactory bulb [34].

It is believed that the central department of the olfactory sensory system is localized in the hippocampus and the hippocampal gyrus, where the final analysis of olfactory information takes place. However, recent studies have shown the role of orbitophronal and pearshaped cortex and almond-shaped body in the processing of olfactory stimuli. Thus, the orbitofrontal cortex is a central substrate for a conscious olfactory experience because of its privileged physiological role in the processing of odor [34].

Separate studies show varying sensitivity to certain odorants in men and women, while significant gender differences in the structure of the leading part of the olfactory analyzer have not been identified, which suggests the expediency of further in-depth studies of the peculiarities of the structural organization of olfactory bulbs and olfactory epithelium. At the same time, the age factor significantly influences the olfactory perception, which is associated with changes in the hormonal status of the human body during the process of ontogenesis [16].

Olfactory dysfunction is a fairly widespread symptom of many neurodegenerative diseases, which is probably due to lesions of mediator systems at different levels of the analyzer. The disturbance of smelling capacity is definitely not a pathology that threatens human life, therefore, often remain unnoticed. However, they can directly affect the quality of life, as they lead to malnutrition and certain problems in interpersonal relationships [2,5].

There are studies that confirm changes in the size of olfactory bulbs and, as a consequence of the development of olfactory dysfunction, in patients with psychotic and neurological disorders. Thus, under the conditions of the physiological aging process, the total number of neurons in olfactory bulbs does not decrease, whereas in the case of Alzheimer's disease there is a process of loss of nerve cells. The first stage of the development of non-motor disorders in Parkinson's disease is characterized by the degeneration of the olfactory bulb and anterior olfactory nucleus, which can clinically manifest as a violation of the olfactory $[12,17,18]$

In general, any changes in the environment affect the smell of human perception, especially the degree of pollution of the atmospheric air. A number of technological processes are accompanied by the release of odorants that are in safe concentrations for human health [24]. However, current research suggests a connection between the state of the air environment and the presence of olfactory dysfunction [8]. Some of these agents can not only directly affect the olfactory epithelium, but also penetrate into the brain through the olfactory nerve or surrounding perineural spaces, passing the blood-brain enzyme barrier and damaging the structures of the central nervous system. Pathological processes that arise under these conditions resemble those with neurodegenerative diseases. It should be noted that especially wood and wood dust, metal compounds and organic substances contained in the air environment of industrial production are particularly dangerous [6].

Damage to the olfactory analyzer can be reversible and irreversible, depending on the individual susceptibility of the human body, which is determined by the resistance of peripheral tissues and the functional state of the conductive part of the olfactory analyzer.

Thus, as a result of short-term intense effects of the pollutant, irreversible atrophic changes are primarily noticed in the olfactory epithelium, thus, to some extent, preventing the spread of the toxin to other analyzer structures. Conversely, long-term exposure to low doses usually maintains the functional activity of the olfactory epithelium, while harmful substances are translated into the olfactory bulbs and migrate to the brain structures. In such cases, the olfactory dysfunction can be diagnosed after a long time after the start of the cohort with certain pollutants. Some studies indicate a high sensitivity of the olfactory pathway to the direct translocation of the 
nanoparticles of the pollutants into cerebral structures $[3,19,21]$.

A significant number of epidemiological studies indicate a connection between the influence of metals in the form of dust and vapors, as well as professional olfactory dysfunction. Workers who were included in the study were often subjected to a combined exposure to cadmium and nickel, but the data on the effect of isolating the latter is not enough. Scientists indicate that with the combined effect of these two metals, patients experienced anosmia, atrophy of the nasal mucosa, chronic sinusitis and ulcers of the nasal membrane [8].

Currently, studies on the influence of exogenous toxins on various parts of the olfactory analyzer on animal experimental models are quite active [29,30,33]. At the same time, the issues of functional-morphological changes in the various structural components of the human olfactory analyzer under the influence of negative environmental factors remain poorly understood and require further morphological and biochemical studies, the results of which in turn may form the theoretical basis for the development of new, effective protective devices.

\section{References}

1. Angelo K, Rancz EA, Pimentel D, Hundahl Ch, Hannibal J, Fleischmann $A$ et al. A biophysical signature of network affiliation and sensory processing in mitral cells. Nature. 2012;488:375-378.

2. Attems $\mathrm{J}$, Walker $\mathrm{L}$, Jellinger $\mathrm{KA}$. Olfactory bulb involvement in neurodegenerative diseases. Acta Neuropathologica. 2014;4(127):459-475.

3. Azuma K, Uchiyama I, Uchiyama S, Kunugita N. Assessment of inhalation exposure to indoor air pollutants: Screening for health risks of multiple pollutants in Japanese dwellings. Environmental Research. 2016;145:39-49.

4. Blotskiy AA. Miklyayeva NV. Grinko OA. Osobennosti techeniya sinusitov u patsiyentov starshey vozrastnoy gruppy. In: Blotskiy AA, editor. Materialy mezhregionalnoy nauchnoprakticheskoy konferentsii otorinolaringologov Sibiri i Dalnego Vostoka s mezhdunarodnym uchastiyem. Aktualnyye voprosy otorinolaringologii; 2018 Jun 28-29; Blagoveshchensk. Blagoveshchensk: FHBOU VO AHMA MZ RF; 2018:194-200. [in Russian].

5. Bohdanov WV, Zavadskyi AV, Bohdanov VV. Narusheniya obonyaniya i kachestva zhizni. Rinologiya. 2012;4:65-71. [in Russian].

6. Buron G, Hacquemand R, Pourié G, Brand G. Carbon dioxide effects on olfactory functioning: Behavioral, histological and immunohistochemical measurements. Toxicology Letters. 2009;188(3):251-257.

7. Djomyna EN, Kastyro YV, Popadiuk VY, Blahonravov ML. Sovremennyi vzghliad na fyzyolohyiu oboniatelnoho y vkusovoho analyzatorov s tochky zrenyia LOR-patolohyy. Rossyyskaya otorynolarynholohyya. 2015;6(79):75-83. [in Russian].

8. Doty RL. Neurotoxic exposure and impairment of the chemical senses of taste and smell. Handb Clin Neurol. 2015;131:299-324.

9. Economo $\mathrm{MN}$, Hansen $\mathrm{KR}$, Wachowiak M. Control of Mitral/Tufted Cell Output by Selective Inhibition among Olfactory Bulb Glomeruli. Neuron. 2016;2(91):397-441.

10. Friedrich RV, Wiechert MT.Neuronal circuits and computations: Pattern decorrelation in the olfactory bulb. FEBS Letters. 2014;15(588):2504-2513.

11. Harvey BS, Weiming Yu. Maturation and Dysgenesis of the Human Olfactory Bulb. Brain Pathology. 2015; 26:301-318.

12. Karaban IM. Khvoroba parkinsona patohenetychni aspekty medykamentoznoi terapii ta klinichnoho perebihu. Naukovyy zhurnal MOZ ukrayiny. 2014;2(6):60-70 [in Ukrainian].

13. Kensaku M. The Olfactory System: From Odor Molecules to Motivational Behaviors. Tokyo: Springer; 2014. 205p.

14. Kikuta Sh, Fletcher ML, Homma R, Yamasoba T, Nagayama Sh. Odorant Response Properties of Individual Neurons in an Olfactory Glomerular Module. Neuron. 2013;6(77):1122-1135.
15. Kosaka T, Kosaka K. "Interneurons" in the olfactory bulb revisited. Neuroscience Research. 2011;2(69):93-99.

16. Lazzari M, Bettini S, Milani L, Maurizii MG, Franceschini V. Differential nickel-induced responses of olfactory sensory neuron populations in zebrafish. Aquatic Toxicology. 2019;206:14-23.

17. Li W, Lopez L, Osher J, Howars JD, Parrish TD, Gottfried JA. Right Orbitofrontal Cortex Mediates Conscious Olfactory Perception. Physiological Science. 2010;10(21):1454-1463.

18. Lucchini RG, Dorman DC, Elder A, Veronesi B. Neurological impacts from inhalation of pollutants and the nose-brain connection. NeuroToxicology. 2012;33(4):838-841.

19. Morozova SV, Savvateyeva DM, Ty'murziyeva AB. Obonyatelnyye rasstroystva u patsiyentov s psikhicheskimi zabolevaniyami. Zhurnal nevrologii i psikhiatrii. 2014;7:73-78. [in Russian].

20. Mukhin VN, Pavlov KI, Klimenko VM. Mekhanizmy umensheniya chislennosti neyronov pri bolezni Altsgeymera. Rossiyskiy fiziologicheskiy zhurnal im. I. M. Sechenova. 2016;2:113-129. [in Russian].

21. Muttray A, Klimek L, Letzel S. Toxische Hyposmie und Rhinitis eines Karosseriebauers und Lackierers. Ergo Med. 2003;27:106-111. [in German].

22. Oliveira-Pinto AV, Santos RM, Coutinho RA, Oliveira LM. [at al.] Sexual Dimorphism in the Human Olfactory Bulb: Females Have More Neurons and Glial Cells than Males. PLOS ONE. 2014;9(11):1-9.

23. Pigolkin Yul, Zolotenkova GV. Vozrastnyie izmeneniya kapillyarov koryi golovnogo mozga. Sudebno-meditsinskaya ekspertiza. 2014;57(1):4-10. [in Russian].

24. Rafieh A, Gholamreza H, Mansoureh S, Mohammad taghi J [at al.]. Gender and age related changes in number of dopaminergic neurons in adult human olfactory bulb. Journal of Chemical Neuroanatomy. 2015;69:1-6

25. Romashchenko AV. Petrovskiy DV. Moshkin MP. Kongruentnost intranazalnoy aerodinamiki i funktsionalnoy neodnorodnosti olfaktornogo epiteliya. Zhurnal obshchey biologii. 2017;1(78):13-24. [in Russian].

26. Rostovtseva LM, Babanina MU, Shkodina AD. Stvorennia zdoroviazberezhuvalnoho seredovyshcha u prymishchenniakh za dopomohoiu fitoremediatsii yak metodu ochyshchennia povitria vid formadelhidu. Materialy rehionalnoi naukovopraktychnoi konferentsii IX Mendelieievski chytannia; 2016 Feb 24; Poltava. Poltava: PNPU im. V.H. Korolenka, 2016:5864. [in Ukrinian].

27. Semenova VM, Medvedev VV. Obonyatelnaya lukovitsa kak istochnik nakopleniya i differentsirovki neyralnykh stvolovykh kletok $v$ postnatalnom mozge cheloveka. Ukrainskyi neirokhirurhichnyi zhurnal. 2014;2:4-9. [in Russian].

28. Shkolnikov VS, Stelmashchuk PO. Suchasni dani pro formoutvorennya ta tsytoarkhitektoniku struktur kintsevoho mozku lyudyny $v$ prenatalnomu periodi ontohenezu. Visnyk Morfolohii. 2015;1(21):268-74. [in Ukrainian].

29. Stepaniuk YaV, Omelkovets YaA, Motuziuk OP. Porivniannia morfolohii osnovnykh niukhovykh tsybulyn deiakykh ssavtsiv. Zoolohiia. 2010;12:85-32. [in Ukrainian].

30. Tian L, Shang Y, Dong J, Inthavong K, Tu J. Human nasal olfactory deposition of inhaled nanoparticles at low to moderate breathing rate. Journal of Aerosol Science. 2017;113:189200.

31. Tykhonova OO, Tarasenko YaA. Peryferychna nervova systema. Poltava:UMSA; 2012. 195s. [in Ukrainian].

32. Voznesenskaya V. Plastichnost obonyatelnoy kommunikatsii. International journal of experimental education. 2012;6:10-12. [in Russian].

33. Werner S, Nies E. Olfactory dysfunction revisited: a reappraisal of work-related olfactory dysfunction caused by chemicals. Journal of Occupational Medicine and Toxicology [Internet]. 2018 Sep [cited 2019 Apr 3];13(2):1-26. Available from: https://doi.org/10.1186/s12995-018-0209-6.

34. Yuan J, Li Q, Niu R, Wang J. Fluoride exposure decreased learning ability and the expressions of the insulin receptor in male mouse hippocampus and olfactory bulb. Chemosphere. 2019;224:71-76.

Матеріал надійшов до редакції 10.04.2019. 